\title{
The Use of Atomic Force Microscopy in The Study of Obstetric Pathology
}

\author{
Tatyana V Pavlova ${ }^{1 *}$, Anton N Kaplin ${ }^{2}$, Elena S Malyutina ${ }^{3}$, Alina V Selivanova ${ }^{4}$ and Lyudmila 0 \\ Zemlianskaya $^{5}$ \\ ${ }^{1}$ Doctor of Medical Sciences, Professor. Department of Pathology, Belgorod National Research University, 85 Victory, Belgorod,
} 308015, Russia

${ }^{2}$ Candidate of Medical Sciences. Department of Pathological Anatomy, Kursk State Medical University, 3 K. Marx, Kursk, Russia

${ }^{3}$ Candidate of Medical Sciences. Department of Pathology, Belgorod National Research University, Russia

${ }^{4}$ Candidate of Medical Sciences. Department of Obstetrics and Gynecology, Belgorod National Research University. Russia

${ }^{5}$ Department of Obstetrics and Gynecology, Belgorod National Research University. Russia

*Corresponding author: Tatyana V Pavlova, Doctor of Medical Sciences, Professor. Department of Pathology, Belgorod National

Research University, 85 Victory, Belgorod, Russia

\begin{tabular}{l}
\hline ARTICLE INFO \\
\hline Received: 幽 October 13, 2020 \\
Published: 幽 October 29, 2020 \\
\hline
\end{tabular}

Citation: Tatyana V P, Anton N K, Elena S M, Alina V S, Lyudmila O Z. The Use of Atomic Force Microscopy in The Study of Obstetric Pathology. Biomed J Sci \& Tech Res 31(3)2020. BJSTR. MS.ID.005110.

\begin{abstract}
The article discusses the use of atomic force microscopy in the study of changes in the histological structure of the tissues of the placenta and myometrium in various types of extragenital pathology in a pregnant woman. The results presented in the article demonstrate what structural changes in the vessels of the placenta and uterus occur in endocrine pathologies (thyroid disease, diabetes mellitus), as well as in preeclampsia.
\end{abstract}

Key words: Atomic Force Microscopy; Placenta, Uterus; Extragenital Pathology; Diabetes Mellitus; Thyroid Gland; Preeclampsia

\section{Introduction}

Changes in the tissue characteristics of the placenta and uterus during pregnancy, occurring against the background of endocrine or other pathology are factors in the development of fetoplacental insufficiency [1]. Identifying patterns between specific changes in the mother-placenta-fetus system and the extragenital pathology that causes them (including using atomic force microscopy) [2] is necessary to develop methods for correcting changes at different stages of their pathogenesis.

\section{Materials and Methods}

\section{During the study were examinated:}
a) 10 women with eythyroidism
b) 45 with hypothyroidism
c) 10 with diffuse toxic goiter (DTG)
d) 16 with gestational diabetes mellitus (GDM)
e) 11 with DM I type
f) 15 with preeclampsia
g) and 10 were the control group

Tissue morphometric analysis was performed using the "Ntegra-Aura" device, atomic force image analysis using standard software NOVA and ImageAnalysis ("NT-MDT"). Statistical analyses were performed using SPSS version 22.0 (IBM).

\section{Results and Discussion \\ Change the configuration of the myometrial vessels in their shape was detected during hypothyroidism, DTG, DM I and preeclampsia. With maternal thyroid disease, endotheliocytes were flatter and thinner due to an increase in vascular area. The greatest changes in the folding of endotheliocytes were observed in groups}


with hypothyroidism, DTG, DM I and preeclampsia. The vascular region free of erythrocytes, blood clots and fibrin decreased in the following sequence of groups: №1 $(35.6 \pm 3.7 \mu \mathrm{m}$ at $28 \pm 2.4$ $\mu \mathrm{m}$ in control), №5 (32.1 \pm 2.6$)$, №2 (12.6 $\pm 1.9 \mu \mathrm{m})$, №4 (11.2 $\pm 1.4 \mu \mathrm{m})$, №3 $(10.3 \pm 1.6 \mu \mathrm{m})$, №6 $(9.3 \pm 1.5 \mu \mathrm{m})$. A decrease in depth, indicating greater tortuosity of the vessels, was observed in group №2 $(7.9 \pm 2.3 \mu \mathrm{m})$, №5 $(7.1 \pm 1.4 \mu \mathrm{m})$, №3 $(6.8 \pm 1.2 \mu \mathrm{m})$, №5 $(6.1 \pm 1.3 \mu \mathrm{m})$, №6 $(5.7 \pm 1.9 \mu \mathrm{m})$. Herewith, in the endothelial microstructure, cytoplasmic bridges and small porous deepenings with blood clots and areas of necrosis are clearly manifested. It was revealed that the greatest difference in the stem villis' relief is observed with euthyroidism $(15.5 \pm 4.5 \mu \mathrm{m})$ and this indicator is close to that in the control group - $14.3 \pm 6.5 \mu \mathrm{m}$. But with hypothyroidism and DTG this indicator is less: $8.6 \pm 0.5 \mu \mathrm{m}$ and 7.5 $\pm 0.4 \mu \mathrm{m}$, respectively in all groups, villi of the intermediate type prevailed with a decrease in the number of lateral branches and moderate stromal vascularization. Their length in the group with the euthyroid state was $460 \pm 36 \mu \mathrm{m}$, with hypothyroidism - $690 \pm$ $48 \mu \mathrm{m}$, with DTG $-720 \pm 55 \mu \mathrm{m}, \mathrm{GDM}-420 \pm 42 \mu \mathrm{m}, \mathrm{DM} \mathrm{I}-730 \pm$ $95 \mu \mathrm{m}$, preeclampsia $-710 \pm 101 \mu \mathrm{m}$ (in the control $-300 \pm 30 \mu \mathrm{m}$ ). The relief drop in all groups, respectively, was: $0.9 \pm 0.3 \mu \mathrm{m}, 0.7 \pm$ $0.1 \mu \mathrm{m}, 0.6 \pm 0.2 \mu \mathrm{m}, 0.8 \pm 0.4 \mu \mathrm{m}, 0.6 \pm 0.3 \mu \mathrm{m}, 0.6 \pm 0.3 \mu \mathrm{m}$ (control - $0.7 \pm 0.2 \mu \mathrm{m})$. The vast majority of vessels are full-blooded, with an area of $35.6 \pm 3.7 \mu \mathrm{m}, 23.6 \pm 3.2 \mu \mathrm{m}, 39.2 \pm 2.2 \mu \mathrm{m}, 30.1 \pm 3.1 \mu \mathrm{m}$, $33.6 \pm 6,1 \mu \mathrm{m}, 49.3 \pm 6.6 \mu \mathrm{m}$, respectively (control - $28.7 \pm 2.4 \mu \mathrm{m}$ )

In the research of terminal villi, the studied parameters (growth, vascular zone) were located in the following sequence: GDM,

ISSN: 2574-1241

DOI: $10.26717 /$ BJSTR.2020.31.005110

Tatyana V Pavlova. Biomed J Sci \& Tech Res

(c) (i) This work is licensed under Creative

Submission Link: https://biomedres.us/submit-manuscript.php the state of euthyroidism in the mother with thyroid pathology, hypothyroidism, DTG, preeclampsia and DM I. When calculating the depth of the capillaries of the terminal section, the indicators primarily reflected their tortuosity and were distributed as follows: $3.8 \pm 0.9 \mu \mathrm{m}, 3.7 \pm 0.5 \mu \mathrm{m}, 1.4 \pm 0.1 \mu \mathrm{m} 1.2 \pm 0.2 \mu \mathrm{m}, 3.6 \pm 0.5 \mu \mathrm{m}$, $4.0 \pm 0.6 \mu \mathrm{m}, 4.3 \pm 0.9 \mu \mathrm{m}(4.1 \pm 0.8 \mu \mathrm{m})$. With fetal hypotrophy and hypoxia, the number of loops in vessels decreased, destruction of erythrocytes and their active contact with villus endothelium were observed.

\section{Conclusion}

It was found that in the mother-placenta-fetus structure with pathology of the TG, DM and preeclampsia, multiple structural changes in the villous tree's and myometrium's tissues are observed, which contribute to the progression of fetal hypoxia. These changes include changes in vascular tortuosity, their shape and lenght, decreased the free vascular region, prevailed intermediate type of villis with a decrease in the number of lateral branches, endotelional disfunction.

\section{References}

1. Pavlova TV, Malyutina ES, Selivanova AV, Petrukhin VA, Kaplin AN, et al. (2020) New approaches in assessing the clinical and pathomorphological aspects of obstetric pathology in the structure of the mother-placentafetus using atomic force research. Systematic Reviews in Pharmacy 11(6): 21-25.

2. Kolobov AV (2015) The morphogenesis of the human placenta and its morphofunctional state in the pathology of pregnancy. Vestnik SPbGU. Seriya 11. Medicina (2): 5-18.



